\title{
RAIMUNDO LÚLIO, \\ O ALQUIMISTA DAS DIFERENÇAS
}

Gisela Fonseca Barbosa*

\begin{abstract}
"Tão logo eu seja fundido pelo fogo de Deus
Deus imprime em mim sua própria essência"

Angelus Silesius ${ }^{\star \star}$
\end{abstract}

\begin{abstract}
SÍNTESE - As tensões geradas pela confluência das culturas grega e semita encontram no século XIII um solo fecundo. O necessitarismo grego que faz do mundo uma emanação divina confronta com a amorosa vontade criadora do Deus semita. Essa questão é raiz fundante do pensamento e do agir modernos e tem em Raimundo Lúlio uma importante reflexão que culmina cọm a emergência de um ethos amoroso. Esse resgate ajuda a fundamentar o lugar do homem e sua responsabilidade na atual sociedade tecnológica.
\end{abstract}

ABSTRACT - The tensions generated by the confluence of the Graeco-Roman and Judaeo-Christian cultures found a fertile ground in the 13th century. The Greek necessitarianism that understands the world as a Divine emanation brings face to face with the loving creative will of the Semite God. Such a question is the foot stone of the modem thought and praxis. Raymond Lull represents an important reflexion that culminates with the emergence of the loving ethos. This retaking helps the establishment of man's place and responsability in the modem technological society.

Os problemas, enfrentados hoje na explicitação de uma identidade que dela faça emergir os contornos de um ethos determinante deste fim de século, encontram eco em cada momento histórico específico. A sempre presente pergunta "quem sou?" renova-se dentro de cada contexto. Desde suas origens, no inevitável encontro das culturas ariana e semita, a linguagem da teologia cristã depara-se com uma série de tensões. A história revela a multiplicidade de caminhos e soluções que apontam para importantes perspectivas que pensadores contemporâneos resgatam como ajuda para o caminhar da sociedade humana. ${ }^{1}$ Insuperáveis tensões entre a revelação e o mistério, cognoscibilidade e incompreensibilidade, afirmação e negação, linguagem e inefabilidade, imanência e transcendência, fé e razão, ga-

- Juiz de fora - Minas Gerais.

* SILESIUS, Angelus. Der cherubunische Wandersmann. Zürich: Diogenes Taschenbuch, 1979. 96p. p. 43.

1 Hans Urs Von Balthasar, Hans Jonas, Félix Alexander Pastor, Henrique de Lima Vaz.

\begin{tabular}{|l|l|l|l|l|l|}
\hline VERTTAS & Porto Alegre & v. 40 & $\mathrm{n}^{\circ} 159$ & Setembro 1995 & p. 623-638 \\
\hline
\end{tabular}


nham riqueza de nuances quando a profunda integração do Deus da filosofia com o Deus da revelação, típica da via platônico-cristã, dissolve-se na subordinação da razão à fé, típica da via aristotélico-cristã. ${ }^{2} \mathrm{O}$ espaço aonde se dá este encontro é um dos solos mais férteis da cultura ocidental: o século XIII europeu. Daí parte a grande rota do pensamento escolástico de que Raimundo Lúlio é, simultaneamente, representante e contra-exemplo.

$\mathrm{O}$ encontro da filosofia greco-romana com a cultura judaico-cristã produziu um fácil diálogo entre o pensamento platônico e neoplatônico e a revelação bíblica, ainda que não sem confrontos e choques. Surge aí um primeiro intento de recepção do conceito filosófico de Deus. A patrística teve o trabalho de demonstrar que o Deus revelado era também o Deus misterioso e universal, princípio último da realidade (arché) da ontologia grega. Mesmo o estoicismo proporcionava uma possibilidade de linguagem adequada à descrição do caráter extático da experiência religiosa. Procurava-se criar uma linguagem teológica que traduzisse a experiência bíblica da revelação e da salvação em categorias aptas a torná-las compreendidas pelo mundo cultural do helenismo. Mas o sincretismo defronta-se com raízes metafísicas incompativeis. Alguns elementos não eram passíveis de tradução. Na transposição dos elementos semitas do campo da fé para o pensamento filosófico, a complexidade da mediação começa da necessária transgressão da religião, cuja base é a fé, para encaixar-se na filosofia, cuja base é a razão. Porém, a revelação clama pela mais alta verdade, e pela mais importante das verdades, com a qual a filosofia é concernente, tocando, assim, no âmago mesmo da filosofia e, num encontro real, afeta toda sua estratégia. Ainda que "filosofia cristã" seja uma contradição de termos, é no âmbito mesmo da filosofia que se desenvolvem as questões de assimilação da verdade cristã. Ocorre um contraponto no curso da dialética religião/filosofia, mais que a imposição à filosofia de temas alheios. A filosofia é ó trabalho mesmo dos homens que se afirmam no filosofar. Participantes de uma herança de fé, certas idéias, escolhas e motivos que a religião revela - ou oculta - dentro do patrimônio da filosofia tornam-se elementos genuínos do campo filosófico modificado. É a legítima continuação da validade e da vitalidade das manifestações existenciais próprias do campo da fé que se extende para aquém do alcance da fé. Essa torna-se premissa do filosofar enquanto conformadora da visão do homem e do mundo que o cerca. Este encontro dá-se de forma que muitos dos aspectos assimilados traduzem-se dentro da razão filosófica, ainda que outros a desafiem por fazer parte de mistérios supra-racionais. Ninguém pode negar que uma filosofia que se pretenda filha legítima do cristianismo possua a característica imprescindível de que a esfera da verdade racional não se encontra hermeticamente fechada dentro das fronteiras de um saber adquirido ou adquirivel pela inteligência e outros recursos exclusivamente humanos, ou seja, um saber qualificado de filosófico ou empiricamente científico no sentido ordinário da palavra. Sempre haverá um espaço aberto à possibilidade autêntica de que a compreensão humana possa ser iluminada com verdades que, por si, sobrepassam os limites de um saber puramente humano e natural, comunicado por uma Inteligência Suprema.

2 PASTOR, Félix Alexander. A lógica do inefável. Trad. Luciano Campos Lavall. São Paulo: Loyola, 1989. 186p. p. 11. 
Sendo a tradição filosófica ocidental classicamente grega, o estudo da tradição cristã em si, e dos elementos filosóficos que não têm origem no pensamento grego - como os aspectos judaicos, por exemplo - são, por conseguinte, determinantes da herança religiosa e que hoje confluem na fundamentação do mundo contemporâneo.

\section{1 - O mundo necessário e o mundo querido}

Um importante tema de confronto introduzido pela fé cristã, que se chocou com o pensamento greco-romano, e que tem profundas conseqüências na apreensão do sentido existencial do mundo pelos homens, é o criacionismo. Tanto 0 aristotelismo quanto o neoplatonismo descrevem o mundo como coeterno ao princípio incriado. Conseqüentemente, o mundo sensivel pertence de certo modo à natureza divina por extensão, sendo ele mesmo um modo divino do ser. 0 que o torna necessário, pela própria essência de Deus, por ser como é, a divindade necessariamente existe como mundo manifesto e contingente e não pode, em nenhum tempo, não ser. 0 mundo estaria imerso na divindade, portanto residiria em seu grau de inteligibilidade intrínseca, e as coisas manifestas, enquanto participantes da natureza divina, estariam mais próximas ou mais distantes de Deus segundo uma escala de normas dos seres, na qual Deus seria o topo. Uma homogeneidade de seres perpassa a Natureza, o Homem e Deus. Apesar de combaterem assim o ateísmo, presente nos antigos atomistas, que atribuiam o princípio do mundo a um cego e fortuito movimento e jogo de átomos invisiveis e indivisiveis no vazio do não-ser, nenhum dos eminentes representantes gregos ou romanos interpretaram o mundo como tendo um certo início, como sendo criação.

A estrutura do pensamento platônico leva-nos por dois caminhos à presença do divino. As Idéias da Beleza e do Bem, conforme seu Simpósio e A república, são apresentadas como o mais alto e primeiro princípio ontológico. Esses princípios são, em suas transcendências, responsáveis pela essência e pelo ser de tudo aquilo que venha a ser objeto de um conhecimento infalivel, isto é, das formas-idéias do mundo inteligivel. $\mathrm{O}$ que é distinto do mundo da matéria, perceptível pelos sentidos. Ainda que matriz das coisas manifestas, a Beleza do Simpósio é uma força abstrata, impessoal, subsistente, transcendente. Parece que se acerca mais de um Deus de caráter pessoal, responsável direto pela formação do mundo, quando surge no Timeu o personagem-mito do Demiurgo. É um organizador do mundo, que exercita seu ofício utilizando como modelo a ordem e a realidade do mundo inteligivel das Idéias. A partir de um plano anteriormente concebido, prossegue sua necessária decisão de formar e ordenar o universo, sem qualquer liberdade, e somente obedecendo sua generosa abundância e bondade. Há, aqui, uma introdução - ou melhor, uma imitação - do ser e da inteligibilidade das Idéias na matéria-espaço desordenada que se apresentava já existente desde sempre. Do caos criou-se o cosmo, de um estado de não-ser, porque era a matéria caótica e desprovida de qualquer determinação intelegível, foi enriquecida com a perfeição do ser. 0 universo sujeita-se a uma ação constante de fazer-se, sempre composto de coisas que estão se fazendo e que nunca chegam ao ponto em que deixam de ser transitórias. Existe, portanto, um algo do qual, ex quo, e no qual, in quo, graças à influência do 
Demiurgo e das Idéias, aparecem as coisas individuais, sensiveis e perecedoras, sujeitas à geração e à corrupção, características daquilo que está sempre em-sendo e nunca chega a ser. A eternidade, tanto da matéria original quanto das Idéias, excluem o Demiurgo do rol dos deuses criadores por excelência, deixando explícito o problema enfrentado por aqueles que vieram apoiar na filosofia platônica a busca da construção de uma filosofia que pudesse ser classificada como cristã.

Observando, sumariamente, o trabalho de Aristóteles, pode-se identificar o supremo princípio ontológico, de ordem pessoal, ao que ele denomina o Motor Imóvel em sua Física e Metafísica, também descrito como Ato Puro e Inteligência Pensante. Não é ainda agora, em Aristóteles, que se chega à apresentação de uma causa eficiente da qual recebam as coisas moventes, corruptiveis ou incorruptíveis, seu ser e sua existência. A imutabilidade do Ato Puro não deixa espaço para a introdução de uma noção de transformação no Motor Imutável sem entrar em profundas contradições. Encontra-se um principio transcendente talvez mais pessoal e menos ambíguo que o de Platão, mas não se trata de um Deus criador e conservador do mundo. O mundo não é produzido pelo Ato Puro, nem mesmo tal como o Demiurgo platônico, já que sua perfeição transcendente o faz alheio das coisas sujeitas a geração e corrupção. O Ato Puro nem as conhece. Tal conhecimento implicaria em um vínculo de dependência do perfeito para com o imperfeito, o que contradiria a concepção de Ato Puro tal como definida pelo filósofo de Estagira. Mais clara torna-se a distância entre o pensamento aristotélico e a idéia de uma criação do mundo, quando é apresentado o ensinamento sobre a matéria primordial. Esta matéria está presente na composição original de todos os seres como princípio entitativo da substância primordial. Esta matéria prima não está sujeita à corrupção, como os seres sublunares, que são continuamente feitos por ela. Não apresenta começo ou fim, sendo coeterno com o Ato Puro, tão perene quanto o céu que, com suas revoluções e movimentos, perdura por toda a eternidade.

Depois de iniciada a era cristã, sobressai um último grande filósofo da época greco-romana. Plotino é extremamente habilidoso, um pensador religioso que trabalha com consistência a idéia de um Deus distinto de todos os outros entes, tão outro que se afasta de qualquer possivel semelhança com qualquer ente passivel de existência. O Uno de Plotino está tão distante de tudo que dele foi emanado que é melhor dizer que nem de um ser se trata. Com isso, quis que não se pensasse a Unidade Suprema com característica panteísta, para que não se confunda com qualquer nem com todas as coisas singulares que Dele procedem. A permanência de um estado inalterado e em eterna identidade consigo mesmo, em perfeita unidade, é uma das principais prerrogativas do pensamento plotiniano. A criação da alma do mundo parte de uma dualidade introduzida pela Inteligência como primeira emanação da qual surge a multiplicidade das coisas, numa geração sucessiva e necessária, imediata ou mediata. Mesmo a matéria, tão distante da simplicidade do Uno, mais próxima do não-ser e do nada caótico, e de que constitui o mundo das coisas sensiveis, é ela ainda derivada da Unidade Suprema, de forma misteriosa, contudo emanancionista. Encontra-se na própria constituição do Uno a necessidade de emanar, radicada em sua natureza, e onde não se encontra qualquer forma de liberdade ou escolha. Porém, a partir de Origenes, o primeiro grande pensador do cristianismo, pertencente à Escola de Alexandria e o mais alto ponto de articu- 
lação sistematizadora do cristianismo com a filosofia helenistica, instaura-se a metafísica da vontade. Embutindo dentro do universo helenístico-gnóstico a vontade contra a necessidade, tanto mais cristão é quanto mais amoroso se apresenta. Ainda não de todo livre das influências do pensamento grego, a criação do mundo relaciona-se a uma resposta, não inteiramente livre, as diferentes vontades e quereres dos seres espirituais. A tentativa de afirmação desses seres de uma identidade própria e autônoma é a Queda e o estabelecimento da pluralidade. Satã, o primeiro a cair, inaugura o mundo - não o cria. É o seu Principe. O mundo faz-se lugar e espaço da afirmação da autonomia. E torna-se, assim, local de penitência e regeneração, transformando o amor divino em justiça. O retorno é penoso. A vontade de Deus aparece ai influenciada pela vontade dos "outros". A vontade dos seres espirituais foi desviada, e deve ser regenerada. Os principais atores dessa estória são os espíritos anteriores ao espaço-tempo.

Pois a partir de Plotino a temporalidade desvincula-se enfim do cíclico, do retorno eterno, para fundar o tempo cristão, histórico. A alma foi criada para o exercício da escolha, e não da transcendência. $O$ entendimento analítico não consegue alcançar a compreensão pela decomposição do mais simples, mas esta só se dá pelo mais elevado que engendra o mais simples. $O$ entendimento racional está alicerçado na dimensão vertical. Abre-se, aqui, a possibilidade de uma opção "para baixo". A corrupção do intelecto é o seu uso por uma vontade não amorosa.

A questão da origem do mundo foi também tratada pelos gênios muçulmanos. Cabe agora verificar rapidamente como os pensadores medievais não cristãos elaboravam estas idéias. O pensamento árabe encontra-se com a cultura grega a partir do ano de 750, através dos cristãos sírios, que se estruturavam na patrística grega. Sua teologia tem como base o Deus transcendente e criador, ramificação do pensamento bíblico. Daí terem os árabes enfrentado o mesmo problema da noção de criação e contingência frente ao predicado maior da necessidade inteligivel da filosofia grega. A ponte foi construida a partir de Aristóteles, sendo importante ressaltar que um erro literário deu novas feições ao aristotelismo muçulmano: livros de Plotino e Proclo foram atribuidos, sem dúvidas, ao filósofo grego. O caráter neoplatônico que as teologias de Avicena e Averróis apresentam têm origem neste fato. Al-farabi, o mais antigo dos ilustres árabes, entra na história da metafísica como aquele que concebeu e afirmou a distinção real da essência e da existência nos seres contingentes. Avicena retoma a questão afirmando que "cada essência é o que é nas suas notas constitutivas (equinitas est equinitas tantum), indiferente em si à singularidade e à universalidade. Nos indivíduos, a essência é singular. Na inteligência, é universal". ${ }^{3}$ Reside, pois, na existência, o locus do necessitarismo grego. Ainda existe, aqui, a emanação necessária por parte de Deus, criador em ato desde toda a eternidade, na ordem da existência, e existe, como seu complemento, a contingência na ordem das essências dos seres criados. Em Avicena, encontra-se a síntese do Bem platônico, do Ato Puro aristotélico e do Uno plotiniano. É uma teoria emanancionista, onde o Bem, que é a essência de Deus, tende a irradiar sua bondade necessariamente, por meio de várias inteligências emanativas.

3 VAZ, Henrique C. de Lima. Escritos de filosofia: problemas de fronteira. São Paulo: Loyola, 1986. 310p. p. 12. 
Deus não pode assim criar nada diferente do que o fez, já que não se trata de um ato de livre vontade. A existência sobrevém a essência como acidente: o único ser que é absolutamente necessário é Deus, que existe em virtude de sua própria essência. Os vários graus de emanação fazem com que a divindade seja, na verdade, criadora apenas da primeira esfera, que engendra a segunda, e assim sucessivamente. Deus não conhece nenhum objeto singular e concreto.

Mais difícil de conciliar com o pensamento da filosofia cristã é a posição de Averróis. Comentador por excelência de Aristóteles, o árabe da Espanha inaugura um tipo de racionalismo com o qual teremos de lidar sob várias formas na cultura ocidental moderna. Segundo ele, para que a criação tenha sentido, há que entendê-la como uma extração simples de formas que estão potencialmente contidas na matéria prima, que sempre existiu e nunca deixará de existir. Sua metafísica é uma ontologia da substância, e, nela, ser e existir são uma mesma coisa. Não há sentido; nesse contexto filosófico, ocuparem os filósofos dos indivíduos transitórios. A substância é universal e necessária, tão eterna quanto seus movimentos, suas gerações e corrupções. Integra, dessa maneira, o mundo sensivel na ontologia do necessário. A opção de Averróis por Aristóteles, como a autoridade maior, rejeita a opinião e o mito como referenciais de prova. A razão pura é determinante da veracidade do conhecimento, e essa idéia dará novo sentido ao confronto entre razão e fé na escolástica do século XIII, e contra o que Lúlio volta-se com grande ênfase.

A influência judia tem dois nomes como pilares. Avicebron, fiel ao criacionismo bíblico, vê o princípio de tudo na vontade divina. Mas daí em diante, em sua metafísica, a matéria universal, pura potência, é hierarquizada em uma sucessão de formas, bem ao estilo neoplatônico: a cada idéia universal na inteligência corresponde uma forma na estrutura do real. Ficam marcadas, em Avicebron, duas doutrinas: a pluralidade das formas e a universalidade da matéria. Maimônides, influenciado por Averróis, admite um único intelecto agente, manifestado em cada particular que se reúne, após a morte, ao primeiro. Sua postura é decididamente agnosticista. Não cabe à inteligência humana o conhecimento do que Deus é, apenas podemos conhecer que Ele é. O estudo dos atributos divinos conforme desenvolvido por Maimônides está presente nos pensadores medievais, e em Lúlio é de radical importância.

Dirigindo agora nossa atenção para os pensadores cristãos, deparamo-nos com algo bem diverso. A doutrina bíblica da criação do mundo localizada num começo temporal (o mundo é criado com o tempo, e não no tempo) leva à erosão da metafísica clássica e, com ela, transforma todo o caráter da filosofia. Contrapondo a contingência à necessidade, o particular ao universal, a vontade ao intelecto, assegurou o lugar do contingente na filosofia. Acrescentado ao divórcio que a doutrina judaico-cristã estabelece entre a mente e a natureza a partir da separação de Deus do mundo - que eventualmente chegou à moderna divisão entre as filosofias do homem e da natureza - as conseqüências dai advindas são de grande importância, levando o filosofar para novos labores.

A idéia da natureza como participante da essência divina sofre um choque com o monoteísmo cristão, onde, à exceção do homem, toda a criação é, igualmente, de seu criador. Não há nenhuma fagulha da divindade no mundo; apenas o 
homem é feito a sua imagem e semelhança, podendo, assim, ser divinizado por adoção. $O$ divino no mundo é o amor.

A doutrina da eternidade do mundo é arremessada como um desafio da razão para a fé. Tiveram os sábios da fé que mergulhar nos labirintos da razão e tornarem, eles mesmos, filósofos. Os olhos voltaram-se para a "natureza do mundo", onde estava em jogo sua criaturidade. Tratava-se do aspecto da vontade divina, em oposição ao divino intelecto. Sendo o mundo necessária conseqüência da essência divina, esse deve ser, em detalhes, dedutivel a partir do primeiro princípio intelectual. Em sua multiplicidade, isso não ocorre: sua constituição não pode ser deduzida a priori sem contradições. Essa constituição poderia ser outra que não a vigente, sua atual natureza é apenas uma escolha entre todas as possiveis alternativas. E escolha é matéria própria da vontade, colocando assim em evidência a lógica de uma livre e espontânea ação divina em contraposição à concepção emanancionista. A existência é um constante risco. A cada instante pode Deus não mais querer, e tudo mergulhará no nada. Esta perspectiva extremista é encontrada em al-Ghazali (1059-1111), atribuindo toda a causalidade a Deus e negando-a à criatura. As leis de ação e reação não são necessárias, isto é, não se trata de conexões inteligíveis, o que torna qualquer ciência da natureza inviável enquanto vinculada a um ciclo de causalidades. Maimônides (1135-1204) rearticula a discussão, elevando-a a um plano mais alto. Combinou a contingência do todo com a necessidade entre suas partes. Aristotélico e criacionista ao mesmo tempo, reabilita assim a possibilidade de uma ciência da natureza governada pelas leis da física de Aristóteles. Estas leis são essencialmente intramundanas e não aplicáveis ao divino. Não são auto-evidentes nem logicamente dedutíveis, ainda que, sob elas, o todo organiza-se sob uma ordem. A criação como opção atual entre infinitas outras possibilidades está relacionada ao total das coisas existentes, mas cada coisa pertence a um mundo determinado por certa ordem. Ainda que o vir-a-ser de cada elemento do sistema seja determinado por leis passiveis de serem apreendidas pela razão humana, estas leis não são aplicáveis ao conjunto todo, e nada pode ser dito do vir-aser do mundo. O sistema que chamamos mundo possui determinantes internos que não se estendem às relações deste sistema com qualquer coisa que the seja exterior, por exemplo, com Deus. A limitação da razão, imposta pelo criacionismo, reside no conhecimento subjetivo finito da natureza mais do que na finitude das coisas em si. O uso da razão é a experiência dos limites.

$\mathrm{O}$ cerne da questão torna-se então a metafísica da vontade. Em Duns Scoto, o voluntarismo atinge o ponto culminante. É ele o deterninante valorativo da contemplação. A finalidade humana é lograr a visão beatifica de Deus através da vontade. A vontade, o poder e o valor unificam-se em Deus, são graças divinas onde cada um é querido assim como todo o conjunto o é. A redefinição ontológica do particular leva o amor até as últimas conseqüências. Mesmo cada partícula da matéria - princípio passivo onde se imprime a forma - é querida.

Assim podemos determinar algumas características que fazem uma filosofia ser fundamentalmente cristã. Um aspecto imprescindivel é que a esfera da verdade racional não se encontra hermeticamente cerrada dentro das fronteiras de um saber adquirido ou adquirivel exclusivamente pelas inteligências ou outros recursos humanos. Ela sempre estará aberta à possibilidade autêntica de que a mente humana 
possa ser iluminada com verdades que, ainda que por si sobrepassem os limites de um saber puramente humano e natural, uma Inteligência Suprema tem o poder de as comunicar. Deve-se admitir que essas possibilidades nem por isso chegam a formar uma parte da filosofia como tal, pois seguem sendo de uma índole distinta de todos os critérios a que se submetem o saber empirico-racional, seja científico ou filosófico. Mas nem por não formar parte da filosofia como tal o caráter de verdade anula-se. Em suma, nenhum pensamento que se proclame agnóstico da possibilidade de uma verdade para além da verdade filosófica, nem ao menos ainda nenhum pensamento que seja relativista ou cético de toda verdade metafísica podem ser legitimamente designados como parte da filosofia cristã.

Igualmente imprescindível é a afirmação de que existe um Ser Supremo, um Princípio Máximo ontológico, que possa ser identificado com o que a linguagem religiosa chama de Deus. $\mathrm{E}$ como conseqüente dessa premissa racional, aparece uma infinita distância que separa e distingue claramente o Ser Supremo por um lado e o conjunto de outros seres possiveis de existir em um determinado tempo de outro: assim afasta-se qualquer possibilidade de panteísmo que reduza Deus e o mundo a uma só realidade. Nem por isso está se afirmando o extremo oposto dessa premissa que insiste na transcendência irracional da parte do Princípio Primeiro ontológico que não permitiria falar de nenhuma presença e de nenhuma imanência real e significante do divino, eterno e infinito no mundano, no tempo, no finito ou no limitado.

Por fim, de acordo com a afirmativa da singularidade e transcendência do Primeiro Princípio ontológico, a filosofia cristã tem explicitamente pontuado que o mundo e tudo o que ele contém devem tudo o que são e possuem, especialmente o que lhes é de mais intimo e fundamental - seu ser, sua existência - a Outro. Esse Outro é Aquele a quem, desde os começos do pensamento dialético-filosófico cristão é conhecido como o mesmo Ser cujo nome nos foi dado pelo livro do Exxodo com as palavras "ille qui est" (Exxodo, III, 14). E sendo tão distinto e singular sua posição de perfeição absoluta e de unidade tal que Santo Tomás de Aquino não pode dar outro nome filosófico mais apropriado que "ipsum esse subsistens" (Summa Theologiae, I, q. 4, a. 2). Assim tentou denominar Aquele que o mundo com todas suas partes, das maiores às menores, devem seu ser e sua existência, de forma que, quando receberam esses dons originária e imediatamente, receberam-nos de uma maneira total e absoluta. Porque anterior a esse momento não eram nada absolutamente. $\mathrm{E}$ ainda depois de haverem recebido seu ser e serem postos em existência, nem por isso começaram a possuí-los por essência e absoluto direito. É a isso que os cristãos denominam a criação ex nihilo, ou do nada.

Porque é toda a realidade devida a um ato livre de um Deus possuidor da mais perfeita sabedoria, o mundo, onde o homem é um dos habitantes, pode ser objeto do conhecimento autêntico e racional. Contra os gnósticos, é defendendida com determinação pelos primeiros apologistas desde o fim do segundo século, a doutrina de que Deus criou o mundo do nada, entendendo com isso que, ao obrar, não exerceu seu ato de criar sobre uma matéria que havia existido previamente. São representantes dessa época Santo Irineu e Teófilo de Antioquia.

Da Escola de Alexandria, já foi citado Orígenes que afirma a criação da matéria mesma, a matéria que entra e constitui uma parte da substância visível do 
mundo. Ainda que, sob a influência do neoplatonismo e para preservar a imutabilidade que vem unida ao eterno dinamismo próprio da divindade, chegou a ensinar que a criação era uma produção eterna. Entre os padres gregos, São Gregório de Nisa afirma a criação em plena liberdade, por razão de sua infinita bondade, com a qual desejava que outros seres participassem, cada um a sua maneira, do ser. Segundo ele é possivel que os homens não possam entender a maneira de como foram criadas as qualidades primeiras de que se fizeram e foram formados os corpos materiais, contudo, a razão humana conclui e tem por certo que as qualidades primeiras foram feitas do nada.

Santo Agostinho, doutor máximo latino, aproveita-se o quanto pode da perigosa doutrina pagã, exposta principalmente por Plotino, de um emanancionismo necessário. Relacionando-a à produção interior divina no seio da Trindade, não vacila porém em insistir na liberdade que acompanha a criação ad extra. Também influenciados por um radical neoplatonismo, Dionísio Areopagita e seu discipulo irlandês do século oitavo, João Scoto Erígena, tentaram entender e explicar a criação com uma linguagem que beira o emanancionismo e o necessitarismo, muitas vezes tocando o tão temeroso panteísmo, ainda que se veja esforços para a distinção entre o divino e o não divino.

Sem essas confusões lingüisticas e de pensamento encontradas nos escritores muito influenciados pelo neoplatonismo, o Pai da Escolástica, Santo Anselmo, fala clara e diretamente da relação entre o causado e a Causa Suprema na produção dos seres e das coisas finitas a partir do nada. O nihil que faz parte da definição da criação não deve ser interpretado como se significasse alguma coisa. Esse nada não deve ser pensado como se fosse alguma coisa. Quer dizer que o ser e a substância das criaturas, antes de existir coisas distintas de Deus, graças a uma criação originária e primordial, não haviam existido de maneira alguma previamente. Esse nada não foi uma causa ex qua ou cum qua foram compostos os seres criados. ${ }^{4}$

\section{2 - Lúlio e o criacionismo na teologia medieval}

Com isso chegamos ao século XIII. As profundas transformações políticas, sociais e econômicas que tiveram início no século anterior tornam-se mais agudas agora. As rígidas estruturas do mundo feudal estão liquidadas, expande-se o urbanismo, fortalecendo o poder dos soberanos, o desenvolvimento da indústria artesanal e o aparecimento dos primeiros grandes fluxos da economia mercantil. É um primeiro esboço do que seria a Europa moderna, ainda titubeante, porém bem definido em sua direção. No espaço da cultura, o aristotelismo e a literatura árabe-judia chegam junto com as fundações das universidades, cuja função maior é político-religiosa: a afirmação de que a Europa é uma cristandade. Seu nome advém mais por ser um centro para onde convergem estudantes e professores de toda a parte do que por possuir um quadro universal de matérias estudadas e lecionadas. Se foi em Alexandria o encontro entre o platonismo e o cristianismo, é nas universidades que se dará o confronto entre o aristotelismo e a teologia cristã. A tensão entre auctoritas e ratio começa a se fazer cada vez mais presente na busca ardente

4 ARTUS, Walter W. "La creación, señal de la filosofia luliana", Estudios Lulianos 17 (1973), p. 140-4. 
da inteligibilidade no seio da fé. É nesse ponto que se encontra a unidade de inspiração que anima os pensadores cristãos desse período. ${ }^{5} \mathrm{~A}$ filosofia escolástica resultou de um encontro bastante consciente entre o cristianismo e o pensamento herdado dos filósofos gregos. $\mathrm{O}$ que até esse dia havia sido mencionado mais como uma parte da síntese total da sabedoria dos pensadores cristãos, agora será dito com plena consciência de seu significado e importância filosófica.

Alexandre de Hales, primeiro mestre dos frades menores na Universidade de Paris, afirma Deus como causa imediata e criadora do mundo, tanto quando toca a matéria quanto a forma. $\mathrm{E}$ essa é uma das verdades que a razão humana pode demonstrar, assim como o pode fazer com o principio temporal. São Boaventura, seu aluno, compartilha com sua idéia, assim como o dominicano Santo Tomás. Estão de acordo com a posição cristã de que o mundo foi efetivamente produto da criação livre e que sua estrutura ontológica reproduz fielmente o conhecimento exemplar da presença do mundo e de todas as coisas na Inteligência divina. Porém São Boaventura, em desacordo com Aristóteles e Tomás de Aquino, afirma a contradição óbvia entre as afirmações de um mundo que seja criado e eterno. Um mundo eterno, que pudesse não haver começado a existir, seria um ente criado que se bastaria a si mesmo, ao menos quanto a sua existência e seu ser, que os possuiria desde toda a eternidade. Assim, um mundo criado deve ter como precedente um não-ser, incompatível com a proposta de sua eternidade.

Tanto Santo Alberto Magno como Santo Tomás de Aquino vêm, contra os franciscanos, afirmar que a razão humana, e com ela a filosofia, não é capaz de demonstrar conclusivamente a impossibilidade de uma criação eterna. Santo Tomás de Aquino, sobre a criação, distingue entre o ex nihilo (do nada), e o post nihil (depois do nada): se tem ou não o mundo um início no tempo, quando ou não começa o mundo a existir. $\mathrm{O}$ ato e a obra de criação devem ser descritos sempre como produto de uma inteligência e uma vontade livres e perfeitas, sendo estas totalmente idênticas com o ser e a essência do Supremo Ser, sem que por isso seja a criação ou o criado algo que brota de Deus com uma necessidade radicada em sua natureza.

Mais para o fim desse período, encontramos Duns Scoto (que alguns historiadores colocam dialogando com Lúlio em aulas parisienses). Nele encontramos as mais profundas conseqüências filosóficas do confronto desse problema entre o necessitarismo e o voluntarismo. Proclamando a primazia da vontade em ambos os planos humano e divino, significa para nós que o domínio do intelecto é feito pela vontade. É a vontade que orienta o pensamento neutro para o objeto, escolhendoo. Quando a vontade é iluminada por insights do pensamento, os insights acontecem a serviço de uma inclinação da vontade, ativando-a para o objeto. É, portanto, a que faz com que a inteligência tome sua reta direção, sendo a primeira na ordem das causas e das atualidades. Como o "intelecto ativo" aristotélico, temos aqui a "vontade ativa" como o princípio movente do intelecto passivo. $\mathrm{E}$ a vontade, por outro lado, não possui nenhuma outra causa senão ela mesma, é livre na radical indeterminação. E não é só no campo do intelecto que a primazia da vontade é efetiva. Assim, a lista de proposições racionalmente não demonstráveis é para Duns

5 VAZ, Henrique C. de Lima. Escritos de filosofia: problemas de fronteira. São Paulo: Loyola, 1986. 310p. p. 21-4. 
Scoto bem vasta. Os mistérios cristãos, como referidos à fé, fazem parte do que é determinado pela vontade. E não é a fé um substituto temporário ou um campo epistemológico da vontade que seria realizada numa consumação futura. A beatitude faz parte da esfera do volitivo. Quebra-se aqui uma tradição milenar que sempre entendeu a consumação relacionada com um estágio do intelecto.

$\mathrm{O}$ que $\mathrm{o}$ intelecto perdeu no alto desse espectro, ele ganha no lado oposto. Agora pode-se compreender a individualidade enquanto individual. Isso só é possivel quando a forma, objeto do conhecimento, não é mais identificada com o universal, e a individualização não é mais mero atributo da matéria. Como realidade última, a existência individual é uma perfeição, não um defeito. Deve haver um princípio formal para cada individual. O principio da individuação tem lugar na esfera ideal, no coração mesmo das coisas. Duns Scoto postula, antiaristotelicamente, a forma da individualidade como necessária, constituinte interno da essência concreta. Está dada a cada indivíduo sua própria forma. A qualidade geral das essencialidades (por exemplo, a humanidade) é complementada pela qualidade individual das formas (por exemplo, a Socratitas). Muito mais amplas são as consequiências filosóficas da primazia da vontade em Deus na doutrina do Doutor Sutil. A regra suprema é a Sua vontade; as coisas são porque Ele as quer. As implicações na lei moral, após a inversão do caráter do intelecto agora subordinado à vontade, traz, como conseqüência, o bem de algo que consiste no ser querido por Ele. Se nos clássicos encontramos deuses caprichosos que devem agir segundo o princípio do certo e do errado que advém do conhecimento do que é o bom e o ruim em si, temos no monoteísmo a questão da onipotência de um Deus, que deveria ser menor se limitada por leis da razão eterna. Na virtude do poder absoluto de Deus, outra ordem moral é possivel. ${ }^{6}$

A renascença do século XIII apresenta sua estrutura econômica, social e política reorganizada. A vigorosa vida intelectual conseqüente da urbanização que fez com que as escolas expandissem em universidades marca esse século. O cristianismo, ao contrário do que se pensa, era uma religião das elites. A religião popular era um misto sincrético do cristianismo com antigas religiosidades germânicas, celtas ou orientais, como o maniqueísmo. ${ }^{7}$ Porém entre as elites letradas, forma-se o substrato intelectual da nova civilização. Atingindo seu esplendor no século XIII, a teologia medieval era a portadora da cultura clássica incorporada à teologia cristã. A herança grega chega até a Idade Média latina através dos árabes. A tarefa que se impunha então era a de mostrar que a sabedoria antiga, recolhida pelo cristianismo, encontrava, no mundo cristão, uma forma superior de manifestação e presença. A teologia medieval segue dois pólos de trabalho epistemológico. A alegoria do mundo, como primeira forma, é derivada da estreita relação com a Escritura Sagrada. O mundo apresentava-se como alegoria do mundo divino intermediado pela Bíblia. Descia-se dos planos superiores, através de símbolos, à grande verdade da realidade das coisas, que a eles retornava quando em uma contemplação teologal. A segunda forma aparece com a ciência do mundo, quando o homem

6 JONAS, Hans. Philosophical essays: from ancient creed to technological man. Chicago: The University of Chigaco Press, 1980. 349p. p. 41.

7 VAZ, Henrique C. de Lima. Escritos de filosofia: problemas de fronteira. São Paulo: Loyola, 1986. 310p. p. 79. 
sente de perto a realidade da organização de uma sociedade e do trabalho que surge junto com a urbanização. É aqui que surge Aristóteles, e o conteúdo da teologia simbólica é reorganizada nas categorias científicas aristotélicas. O problema fundamental dos teólogos do século XIII é o problema das essências e das naturezas. Da sua intrínseca necessidade e inteligibilidade, a força criadora mostra sua radical contingência. O rigor intelectual da filosofia grega impõe-se à descoberta de uma natureza participante das essências, das causas eficientes e fins. A matriz teológica torna-se modelo de solução de toda problemática medieval, desde os problemas da história, da política e da ética até da medicina e das artes. A Idade Média já não é plenamente sacral, suas soluções não são buscadas apenas nos planos sobrenaturais e divinos. Instalada a razão interrogante, a fé teologiza, volta-se sobre si mesma, utiliza-se do instrumento do logos para ver até que ponto ele é aceitável como comprovador das glórias de Deus. Por isso, é a Idade Média atravessada por grandes querelas intelectuais.

É preciso ter em mente que o trabalho intelectual desenvolvido pelos doutores e cultos teve o dever da preservação de um legado ocidental do pensamento. A cultura medieval é parametrizada por esse trabalho teológico, por um lado, e pelas profundas transformações na vida do povo que sai dos feudos para as cidades, por outro. Eles não tinham o mesmo tipo de preocupações. E aqui encontramos o que Raimundo Lúlio tem de mais peculiar. Como homem de seu tempo, participa ativamente de todo o labor medieval de assimilação de Aristóteles através dos intermediários árabes, dentro da linha de Santo Anselmo, São Boaventura e Duns Scoto. Mas não se basta aí. A necessidade de cristianizar os homens do povo, ensiná-los a pensar, refletir sobre seus atos e sua vida como responsáveis que são pelo seu destino e sua salvação colocam o Doutor Iluminado como pioneiro na popularização do trabalho intelectual. E é nesse sentido que Lúlio torna-se contra-exemplo de seu tempo. Diverso de toda a ânsia da elite intelectual, participante dela, porém, a excedia na profunda humanidade. $O$ desejo incontido de levar consigo em sua viagem mística e espiritual toda a espécie humana torna-o um ponto fora da curva. Se toda a problemática teórica o envolve como uma série de questões fundamentais a serem resolvidas, todos devem participar de forma ativa das conclusões que o intelecto propunha. $O$ engajamento luliano faz inveja a qualquer ativista de nosso século.

$O$ estudo das correntes filosóficas que conformariam o pensamento do século XIII é extremamente mais complexa que a história dos problemas. A questão do criacionismo é apenas um parâmetro, entre tantos, que por si só não caracteriza a originalidade dos pensadores dessa época. Os problemas filosóficos não têm para eles a significação independentemente das repercussões teológicas que trazem consigo. ${ }^{8} \mathrm{O}$ critério adotado de seguir o desenvolvimento das soluções buscadas para um determinado problema, no caso o criacionismo, foi estabelecido perante a necessidade do tema. É a partir da explicitação da volição como fundamento mesmo do mundo que aparece a alteridade como discussão num plano mais alto e profundo. O Outro radical, para além da pluralidade e da multiplicidade, torna-se a pedra fundamental do ethos, que passa a depender de um contrato muito maior do que os estabelecidos apenas entre os homens. Sem cometer anacronismos, posto

$8 \quad$ ibidem, p. 27. 
que a Aliança já encontra-se no Antigo Testamento e a idéia de contratos torna-se assim milenar, é num relembrar desse contrato que buscamos, junto com pensadores contemporâneos, restabelecer o fio que poderá nos levar de volta à saída do labirinto moderno no qual nos metemos. Retornamos assim a nosso guia, Raimundo Lúlio.

Lúlio pertence à família de Santo Agostinho e Santo Anselmo, que jamais teriam como sacrilégio o máximo uso, porém com reverência, da inteligência que nos foi dada pelo Criador, com o propósito de obter algum conhecimento sobre as verdades que antes eram aceitas pela fé. Alguns historiadores o acusam de antecipador do racionalismo extremo por ter aplicado a mente nos mais altos mistérios da fé. Encontra-se, em vários pontos de sua obra, profundas especulações sobre cada um dos pontos da criação divina de tudo aquilo que não é Deus, uma convicção firme da transcendência segundo a qual Deus é decididamente distinto por ser o Outro de tudo que não é Ele, de tudo que é finito ou contingente. Não foi, nem nunca será possivel, que o infinito abismo ontológico que separa o Ser-por-Essência e os seres por participação diminua qualquer ínfima distância, nem no caso da mais perfeita das criaturas, que como tais continuam participando do ser graças ao Outro pelo qual existem. A criatura sempre permanece outro ser, outra coisa, outra realidade distinta de Deus. Nunca será capaz de diminuir em nada a contingência e o finito que sempre o distinguiram radicalmente dAquele que lhe deu o ser, privado do qual nada seria. "Entre o finito e o infinito não existe proporção alguma," afirma.

Sobre a duração do mundo, isto é, sua possível ou não eternidade, escreve:

\begin{abstract}
"Se o céu é eterno, possui então o poder de existir eternamente por si mesmo posto que nunca esteve em um estado potencial para com seu ser (pois sempre existiu). Porém não se pode dizer, naturalmente, que se faça no momento presente em estado de potência para com seu não-ser. Por conseguinte, fora tal caso (i. e., que o céu fosse eterno) nem a bondade nem o poder de Deus seriam a causa ou o poder ou a bondade do céu. $E$ o poder de Deus não seria capaz de privar o céu de seu poder posto que o céu então se governaria a si mesmon. ${ }^{9}$
\end{abstract}

Lúlio sabia da singularidade do pensamento que definia o mundo como criatura. Nenhum outro ser que não Deus pode produzir algo do nada, como aconteceu quando o mundo foi criado. $O$ que facilita um pouco a compreensão do porquê, muitos dos mais eruditos e sábios dos homens não puderam conceber ou pensar, nem ao menos imaginar a criação ex nihilo. Em tal situação, o que se faz é ou ignorar - como os gregos - ou negar - como tantos vêm fazendo em nossos dias de modernidade. Pois qualquer outra produção da qual temos experiência é radicalmente diferente da criação do universo. Produzir algo totalmente, tirando-o do nada, sem se utilizar de nada que já existisse previamente, ou de qualquer instrumento, é o que Lúlio estabelece como distinção do criar e do fazer. A consciência do diferente e do singular que ocasiona a criação do mundo aparece no léxico de sua doutrina de causas, quando se fala de criar algo do nada; devendo entender-se que não se dispõe nem de uma causa material nem de uma formal, nem de um instrumental que tenham precedido ao que é criado em algum modo de existência

9 ARTUS, Walter W. "La creación, señal de la filosofia luliana", Estudios Lulianos 17 (1973), p. 150, citando Lúlio em sua Ars generalis ultima. 
autêntica e separada. Antes de receberem o ser, o mundo e as criaturas não eram absolutamente nada; e ainda depois de que foram criadas, não se pode dizer que houvessem recebido um ser que era antes possuido por algo. Deus era o único que existia em sua eternidade. $\mathrm{E}$, evitando o panteísmo, incompativel com a doutrina cristä, não se pode pensar que Deus tenha utilizado sua mesma substância e seu poder para fazer deles a substância do mundo. Assim, nada compromete a transcendência e a imutabilidade divinas.

Introduzindo sua visão exemplarista da realidade, diferente de qualquer forma de panteismo, Lúlio utiliza-se dos símbolos do selo e do espelho:

\begin{abstract}
"Quando uma imagem ou figura apresenta-se frente a um espelho, ela se forma no espelho, que recebeu a imagem de algo que se encontra fora de si mesmo; e isto sem emitir nada de sua própria essência ou natureza. Igual coisa ocorre quando o selo imprime sua figura na cera sem perder nada de sua própria essência ou natureza. Do mesmo modo, o mundo e suas partes são feitas na mente divina por meio de uma ou várias idéias sem que a divina inteligência perca ou retire de si algo de sua própria essência e natureza, ou de seus atributos. Portanto, quando Deus criou o mundo, no ato de criar não emitiu de si nada do ser da idéia. Se tivesse retirado ou perdido algo, indiscutivelmente a idéia teria se alterado, e então já não seria eterna, o que é impossivel, posto que a idéia é Deus mesmo. Contudo quis a vontade divina que do nada fosse criado isso que Ele tem desde toda a eternidade mediante a idéia". ${ }^{10}$
\end{abstract}

Os filósofos antigos opinavam que do nada nada se faz, pois assim julgavam pelas produções ordinárias e naturais de que o homem tem experiência, e pela experiência universal de que nada não é uma realidade e que não é redutivel a nenhuma causa efetiva ou operativa. Porém a única conseqüência dedutivel dai é que a última razão e explicação da produção do mundo devem ser buscadas no poder infinito e na vontade efetiva de Deus Criador. As dificuldades para a nossa inteligência e, mais, para nossa imaginação, não desaparecem quando se tenta estabelecer o feito da criação ex nihilo. Parece que se deve esperar que quando se fala acerca das raizes da realidade e da nossa existência, não se evaporem todas as ambigüidades e mistérios. Assim deve realmente ser quando se trata de entender algo que se apresenta à nossa inteligência, sendo que esse algo está relacionado ao que se opõe totalmente ao objeto próprio e adequado à inteligência mesma: aquilo que tem o caráter - se assim é lícito dizer - do nada. A dificuldade de tal situação é explicitada na Ars generalis ultima, onde Lúlio escreve que o entendimento humano não compreende o nada. Porque no nada a inteligência é incapaz de entender coisa alguma, nem entender que desse nada se faça algo. Conseqüentemente, "não somos capazes de entender nada disso onde não há nada que se possa entender".

A criação aparece claramente como obra da vontade e da liberdade divinas, unidas e identificadas com os outros atributos divinos, ou dignidades. A identidade e conseqüente convertibilidade das dignidades e princípios gerais dentro da divindade exigem essa posição onde se atém a origem livre e voluntária do mundo. "De outro lado, na perfeita vontade divina - uma vontade que tem poder e sabedoria perfeitos - é possível entender como Deus pode fazer algo do nada. Daí resulta que 
sua vontade o pode querer, seu poder o pode fazer e sua sabedoria o sabe fazer e criar". 11

É a ignorância dessas verdades e da distinção entre as produções ad intra e ad extra da divindade, as obras e vida que ocorrem no interior mesmo da divindade, por um lado, e as que lhe são exteriores, por outro, que ocasiona a opinião daqueles que acreditam que a criação tenha ocorrido sem nenhuma liberdade por parte de Deus. Devido à

\begin{abstract}
"notícia imperfeita que esses filósofos tiveram do poder, da vontade e sabedoria divinos, e da perfeição destes, foram da opiniāo de que o firmamento e os corpos celestes existem etemamente e sem começo. A principal razão do porquê os filósofos quiseram provar que o mundo é eterno foi para poder atribuir uma grande honra e nobreza à Causa Primeira, a Deus. Os ditos filósofos trouxeram da Causa Primeira o conhecimento das coisas, e declararam que assim como a Causa Primeira é a causa e o fim de todas as coisas, e assim como Ela é eterna, assim convém que seu efeito, o que Ela causou, seja igualmente eterno. Tal efeito segundo eles era o mundo". ${ }^{12}$
\end{abstract}

Nunca teve Lúlio qualquer dúvida sobre a livre criação do universo, que tivesse sido criado não por necessidade para que Deus pudesse continuar sendo vivo e ativo. A obra interior ad intra precedeu eternamente o mundo, é e será por toda a eternidade uma obra perfeita e infinita. A criação começou com o primeiro momento do tempo. Para o Doutor Iluminado não pode Deus criar um mundo eterno. Evitando que sua idéia fosse mal interpretada, colocando limites no poder do Criador, Lúlio reduz a impossibilidade à caducidade da criatura como tal. Uma de suas raízes ônticas é a minoridade, sua proximidade ao não-ser. Nota-se, nas definições de criatura, o conceito de sucessão, pressupondo assim que na aparição inicial do que foi feito e dado o ser, sem necessidade alguma, seu ser vem depois do que não foi: "a criatura é esta realidade que tem o ser depois de não-ser". ${ }^{13}$

Na sua infinita Grandeza, Deus não pode produzir um ser de infinita extensão (o que implica em contradição), um infinito distinto de Si mesmo em duração. Se isso ocorresse, Deus deixaria de o ser, pois haveria outro de Si igual, ao menos por uma eterna duração, tudo isso sendo contraditório e, portanto, impossivel. Por isso, Deus não pode criar um mundo ou uma criatura eterna. O problema não é um suposto limite no infinito poder divino, em todo perfeito e onipotente, para quem tudo o que pode ser é ipso facto e sob seu poder. Se uma criação eterna é impossível, é porque indicaria uma contradição.

A filosofia cristã, segundo o pensamento luliano, abre a porta da sabedoria mais alta que nos é dada como um dom que vem do alto. A criação efetuada por uma Bondade onipotente é o motivo do otimismo luliano de crer na maior perfeição que pode manifestar suas criaturas. ${ }^{14}$ Se é na vontade que reside o maior atributo divino pela sua atualidade - não por sua extensão ou poder - é aí que encontramos a ponte para a compreensão do homem em seu estar-no-mundo, ai encontramos as diretrizes de um comportamento virtuoso e bom, e aí descobrimos a verdadeira

11 ibidem, p. 159, citando Lúlio em seu Libre del gentil, p. 1078, v. 1.

12 ibidem, p. 160, citando Lúlio em seu Libre del gentil.

13 ibidem, p. 161, citando Lúlio em sua Ars compendiosa inveniendi veritatem, p. 477, v. 1.

14 ibidem, 33p. 
saúde espiritual que faz cada homem responsável por seu caminho e pelo conjunto dos caminhos da espécie humana.

Assim é também no ser humano, onde - entre as potências da alma: a memória, a inteligência e a vontade - é a vontade a de maior atualidade e, portanto, a direcionadora de um ethos sobre o que Lúlio traçará toda sua obra na intenção de levar a cada indivíduo o conhecimento da necessidade de um reto viver e um reto pensar. É o ethos do amor que pontua todos seus escritos e para o qual os estudos se direcionam no intuito de recuperar nesse pensador e mistico do século XIII uma proposta de identidade humana que restabeleça o sentido da vida nesse final de milênio. 